\title{
EVALUASI PELAKSANAAN PROGRAM UJIAN ONLINE DI SMK NEGERI 4 JAKARTA
}

(Penelitian Evaluatif di Kelas XII Jurusan Teknik Konstruksi Batu Beton SMKN 4 Jakarta)

\author{
Erni Kristiyani ${ }^{1}$, Tuti Iriani ${ }^{2^{*}}$, Rosmawita Saleh ${ }^{3^{*}}$ \\ ${ }^{1}$ Alumni Pendidikan Teknik Bangunan FT UNJ,Jakarta, Indonesia. \\ 2 Pendidikan Teknik Bangunan, FT UNJ, Jakarta, Indonesia. \\ ${ }^{3}$ Pendidikan Teknik Bangunan, FT UNJ, Jakarta, Indonesia \\ *Corresponding author: tutiiriani@unj.ac.id, rosmawitasaleh@unj.ac.id
}

\begin{abstract}
The Objectives of this study to determine whether the online testing program for Class XII students of Stone Concrete Construction Engineering Department at SMK 4 Jakarta has been successful or not. This research was conducted in the Department of Stone Concrete Construction Engineering SMKN 4 Jakarta in July 2013 until November 2013.

The method used is the evaluative research method with the type of CIPP evaluation model (Context, Input, Process, Product), with a sample of 26 students Class XII Stone Concrete Construction Engineering Department, one of teacher Stone Concrete Construction Engineering Department, and Head of IT SMKN 4 Jakarta. The research instrument used online testing, interviews, and questionnaires.

Validity test results, 10 items questionnaire is valid. While the results of the reliability test, $R 11$ value is 0.904 . To access the online testing program, Head of IT requires program of Moodle, server, internet networks, and laptop; the teachers need laptop, Hot Potatoes, and the internet networks; while the students need laptop and internet networks. The curriculum used is the Kurikulum Tingkat Satuan Pendidikan (KTSP). The average score that student obtained from online testing is 72 , and this score is lower than a Kriteria Ketuntasan Minimal (KKM) which has been determined 75. From the calculation of the questionnaire, percentage of successful online testing program is only $56.69 \%$ of the respondents expected. During the implementation of the online testing program, there are some issues such as school wifi network can not be used, the server often down, students must bring their own laptops and modems, and as well as a hot classroom. The impact of online testing program that is obtained by the school teachers and students can operate computers and the Internet as a means of learning evaluation. Thus, the overall implementation of the online testing program at SMK 4 Jakarta can be said to have not succeeded and need for improvement, especially in school's internet networks and facilities to support the online testing program.
\end{abstract}

Keywords: Evaluation, CIPP, Online Testing 


\section{PENDAHULUAN}

Perkembangan teknologi yang pesat semakin banyak memberikan kemudahan bagi masyarakat dunia. Hal ini dikarenakan hampir seluruh aspek dalam kehidupan manusia telah tersentuh oleh teknologi. Teknologi yang saat ini sedang mengalami perkembangan pesat adalah internet (Robert L. Mathis dan John H. Jackson, 2012). Wahyono dan Toruan (2010) menyatakan bahwa salah satu penerapan teknologi internet dalam pembelajaran juga dapat diterapkan dalam pelaksanaan ujian online. Dalam institusi pendidikan, saat ini tercatat baru beberapa lembaga pendidikan yang menggunakan sistem ujian online antara lain SMK Bhara Trikora 1 Jakarta, SMKN 3 Malang, Universitas Gajah Mada, Bina Sarana Informatika, dan SMKN 4 Jakarta.

SMKN 4 Jakarta merupakan salah satu Sekolah Menengah Kejuruan yang terletak di Cilincing, Jakarta Utara dengan 11 program keahlian. Salah satu program keahlian yang diminati di kalangan siswa adalah program keahlian Teknik Konstruksi Batu Beton (TKBB) yang bertujuan untuk mempersiapkan peserta didik untuk bekerja sesuai bidangnya dan membekali peserta didik dengan keterampilan, pengetahuan, dan sikap supaya menjadi tenaga kerja yang kompeten dalam bidangnya (Undang-Undang Sistem Pendidikan Nasional Pasal 3 dan Pasal 15). Program Keahlian Teknik Konstruksi Batu Beton telah menggunakan sistem ujian online sebagai alat evaluasi pembelajaran. Sistem ujian online ini dilaksanakan pada saat UTS dan UAS serta telah berlangsung sejak awal tahun 2010. Guru membuat soal sesuai dengan bidang studi dan kompetensinya, kemudian soal tersebut diunggah ke situs resmi SMKN 4 Jakarta. Setiap siswa diinformasikan terlebih dahulu mengenai jadwal ujian online sebelum ujian tersebut dilaksanakan. Siswa dapat mulai mengerjakan soal ujian sesuai dengan jadwalnya masingmasing.

Soal ujian online berbentuk pilihan ganda dan memiliki lima pilihan jawaban untuk setiap butir pertanyaan dengan satu pilihan jawaban yang benar. Setiap siswa diberikan waktu yang sama untuk mengerjakan soal ujian tersebut. Ketika siswa telah selesai mengerjakan, siswa dapat langsung mengetahui nilai yang diperoleh sedangkan guru dapat memantau siswa yang sudah dan belum mengerjakan soal ujian serta dapat melihat nilai seluruh siswa. Kesalahan penilaian secara manual oleh guru tidak terjadi lagi dalam ujian online ini karena penilaian langsung dilakukan oleh sistem komputer tersebut. Program ujian online ini juga menerapkan sistem blocking situs apabila siswa menggunakan jaringan internet sekolah sehingga tidak dapat membuka situs lain. Namun hal ini menjadi tidak efektif, dikarenakan jaringan internet sekolah sering bermasalah sehingga banyak siswa yang menggunakan modem pribadi. Hal ini memungkinkan siswa dapat dengan bebas mengakses situs lain untuk mencari jawaban.

Berdasarkan uraian latar belakang di atas, pelaksanaan program ujian online di 
SMKN 4 Jakarta ini membutuhkan evaluasi untuk mengetahui apakah program ujian online ini sudah berhasil atau belum. Oleh karena itu, peneliti ingin mengadakan suatu kajian penelitian mengenai Evaluasi Pelaksanaan Program Ujian Online di SMK Negeri 4 Jakarta.

. Berdasarkan identifikasi masalah dan pembatasan masalah di atas, maka secara spesifik perumusan masalah dalam penelitian ini adalah sebagai berikut: Apakah program ujian online bagi siswa Kelas XII Jurusan Teknik Konstruksi Batu Beton di SMKN 4 Jakarta sudah berhasil?

\section{METODE PENELITIAN}

Penelitian ini bertujuan untuk mengetahui apakah program ujian online bagi siswa Kelas XII Jurusan Teknik Konstruksi Batu Beton di SMKN 4 Jakarta sudah berhasil. . Tempat untuk melaksanakan penelitian Evaluasi Pelaksanaan Program Ujian Online di SMK Negeri 4 Jakarta adalah di Jurusan Teknik Konstruksi Batu Beton. Sedangkan untuk waktu penelitian dilaksanakan pada bulan Juli 2013 sampai dengan November 2013

Penelitian ini merupakan penelitian evaluatif dengan model pendekatan evaluasi model CIPP (Context, Input, Process, Product) yang telah dikembangkan oleh Daniel L. Stufflebeam (1967) di Ohio State University (Tayibnafis, 2000). Model CIPP merupakan evaluasi menyeluruh dengan empat tahapan yakni, konteks (context), masukan (input), proses (process), dan produk (product) dari program ujian online
Populasi dalam penelitian ini adalah 30 siswa Kelas XII Kompetensi Keahlian Teknik Konstruksi Batu Beton SMK Negeri 4 Jakarta tahun ajaran 2013/2014, Guru, dan Kepala IT SMK Negeri 4 Jakarta. Dari 30 orang populasi (siswa Kelas XII Jurusan Teknik Konstruksi Batu Beton) yang terjangkau, hanya 26 orang saja yang memenuhi persyaratan. Sehingga, sampel siswa Kelas XII Jurusan TKBB yang digunakan dalam penelitian ini adalah sebanyak 26 siswa.

Dalam penelitian ini, teknik pengumpulan data yang digunakan adalah dengan menggunakan ujian online, wawancara, dan penyebaran kuesioner. Pada instrumen wawancara menggunakan alat instrumen berupa pedoman wawancara yang memuat 20 pertanyaan untuk Kepala IT dan 8 pertanyaan untuk guru. Untuk kuesioner terdiri dari 10 butir pertanyaan dalam bentuk Skalal Likert dengan lima alternatif jawaban yaitu Sangat Setuju, Setuju, Ragu-ragu, Tidak Setuju, dan Sangat Tidak Setuju. Sedangkan untuk tes online bagi siswa Kelas XII Jurusan TKBB, bentuk ujian yang akan digunakan berupa pilihan ganda yang terdiri dari 50 pertanyaan dengan lima pilihan jawaban yang tersedia.

Pada instrumen wawancara, pertanyaan yang telah dijawab, dicatat dan direkam kemudian dirangkum dalam bentuk kesimpulan dari jawaban tersebut, sedangkan pada hasil ujian online siswa didapatkan nilai-nilai dari setiap siswa kemudian dicetak dan dilakukan analisis jawaban siswa pada setiap butir pertanyaan. Untuk kuesioner, sebelum kuesioner digunakan dalam penelitian maka 
terlebih dahulu perlu dilakukan uji coba instrumen kepada responden diluar sampel. Setelah diujicobakan kemudian dilakukan perhitungan validitas dan reliabilitas. Apabila instrumen telah valid dan reliabel, kemudian dilakukan pengambilan data. Setelah data didapat kemudian dilakukan analisis setiap jawaban pilihan responden untuk diteliti. Selanjutnya, untuk menentukan berhasil atau tidaknya program ujian online ini akan diukur dari perbandingan jumlah kelebihan dan kekurangan yang dimiliki oleh program ujian online ini. Selain itu, digunakan pula teknik perhitungan skor kuesioner untuk penelitian evaluative.

\section{HASIL DAN PEMBAHASAN}

\section{Evaluasi Konteks}

Berdasarkan dari hasil wawancara diketahui bahwa latar belakang permasalahan diadakannya program ujian online adalah untuk mengurangi penggunaan kertas (paperless) untuk ujian. Sistem ujian tertulis menggunakan banyak kertas untuk lembar soal dan lembar jawaban yang hanya sekali pakai serta penggunaan tinta yang berbenturan dengan isu lingkungan dimana luas hutan dengan pohonpohon sebagai penghasil utama lembaran kertas semakin menyusut dan masalah sampah yang ditimbulkan setelah penggunaannya. Selain itu, Kepala SMKN 4 Jakarta menginginkan suatu sistem ujian yang lebih mudah, efektif, dan modern sebagai langkah dari pengembangan sistem ujian tertulis.

Tujuan dari program ujian online ini adalah untuk memanfaatkan teknologi yang sudah ada. Setiap siswa baru diwajibkan membeli komputer jinjing (laptop) yang pembeliannya dikoordinir oleh pihak sekolah. Teknologi ini dimanfaatkan oleh pihak sekolah untuk membuat media pembelajaran dan sistem ujian secara online yang memanfaatkan teknologi tersebut. Tujuan lainnya adalah untuk memudahkan guru dalam melaksanakan penilaian dan evaluasi.

Tabel 1. Persentase Jawaban Sampel pada Sub Variabel Tujuan dengan Indikator Hasil yang diharapkan

\begin{tabular}{|l|l|l|c|l|c|c|c|c|c|}
\hline $\begin{array}{c}\text { Sub } \\
\text { Variabel }\end{array}$ & Indikator & \multicolumn{1}{|c|}{$\begin{array}{c}\text { Sub } \\
\text { Indikator }\end{array}$} & No & \multicolumn{1}{|c|}{ Pertanyaan } & SS & S & RG & TS & STS \\
\hline Tujuan & $\begin{array}{l}\text { Hasil } \\
\text { yang } \\
\text { diharapk } \\
\text { an }\end{array}$ & $\begin{array}{l}\text { Kemudahan } \\
\text { dalam } \\
\text { melaksana- } \\
\text { kan ujian }\end{array}$ & 1 & $\begin{array}{l}\text { Program ujian } \\
\text { online } \\
\text { memudahkan saya } \\
\text { dalam } \\
\text { mengerjakan soal- } \\
\text { soal ujian }\end{array}$ & $12 \%$ & $46 \%$ & $15 \%$ & $23 \%$ & $4 \%$ \\
\cline { 2 - 9 } & $\begin{array}{l}\text { Peningkatan } \\
\text { nilai ujian } \\
\text { siswa }\end{array}$ & 2 & $\begin{array}{l}\text { Program ujian } \\
\text { online dapat } \\
\text { meningkatkan nilai } \\
\text { saya }\end{array}$ & $12 \%$ & $12 \%$ & $23 \%$ & $31 \%$ & $23 \%$ \\
\cline { 2 - 9 } & Kecepatan & 3 & Saya langsung & $23 \%$ & $65 \%$ & $4 \%$ & $8 \%$ & $0 \%$ \\
\hline
\end{tabular}




\begin{tabular}{|c|l|l|l|l|l|l|l|l|l|}
\hline $\begin{array}{c}\text { Sub } \\
\text { Variabel }\end{array}$ & Indikator & \multicolumn{1}{|c|}{$\begin{array}{c}\text { Sub } \\
\text { Indikator }\end{array}$} & No & \multicolumn{1}{|c|}{ Pertanyaan } & SS & S & RG & TS & STS \\
\hline & & $\begin{array}{l}\text { penilaian } \\
\text { ujian }\end{array}$ & & $\begin{array}{l}\text { dapat mengetahui } \\
\text { nilai ujian saya } \\
\text { setelah saya } \\
\text { selesai } \\
\text { mengerjakan soal } \\
\text { ujian online }\end{array}$ & & & & & \\
& & & & & & & & \\
\hline
\end{tabular}

Dari hasil penelitian menunjukkan bahwa $46 \%$ responden setuju dan $12 \%$ responden sangat setuju dengan program ujian online yang memudahkan responden dalam mengerjakan soal-soal ujian. Sedangkan 23\% responden tidak setuju dan $4 \%$ responden sangat tidak setuju bahwa program ujian online memudahkan responden dalam mengerjakan soal-soal ujian. Dapat disimpulkan bahwa program ujian online memudahkan 58\% responden dalam mengerjakan soal-soal ujian

Dalam hal peningkatan nilai ujian siswa, $31 \%$ responden menyatakan tidak setuju dan $23 \%$ responden sangat tidak setuju bahwa program ujian online dapat meningkatkan nilai ujian responden. Dapat disimpulkan 54\% responden tidak mengalami peningkatan nilai ujian dengan sistem program ujian online.

Sedangkan dalam hal kecepatan penilaian ujian, siswa dapat langsung mengetahui nilai ujiannya setelah mereka selesai mengerjakan soal ujian online, hal ini dapat ditunjukkan dengan $65 \%$ responden setuju dan $23 \%$ responden menyatakan sangat setuju. Hanya $8 \%$ responden yang mengaku tidak setuju. Dapat dikatakan, 88\% responden dapat mengetahui nilai ujiannya secara langsung.
Program ujian online yang digunakan adalah program open source yang bernama Moodle. Server program ujian online dikelola oleh Kepala IT sebagai pihak yang dipercaya untuk bertanggung jawab terhadap pengelolaan server dan pengembangannya. Saat ini server yang digunakan berjumlah satu buah dan belum ada penambahan server. Hal ini dikarenakan terbatasnya anggaran sekolah. Semua mata pelajaran dapat diujikan dengan sistem ujian online ini dalam bentuk teori yang berkaitan dengan mata pelajaran tersebut. Untuk membuat soal-soal ujian dapat menggunakan software Hot Potatoes. Saat ini pihak sekolah memakai Program Moodle versi 2.6.0 dan software Hot Potatoes versi 6. Sedangkan jaringan internet menggunakan program Astinet dari Telkom dan untuk standar kecepatan jaringan wifi sekolah berkisar antara $40 \mathrm{mbps}-$ $54 \mathrm{mbps}$.

\section{Evaluasi Masukan}

Kurikulum yang saat ini digunakan adalah Kurikulum Tingkat Satuan Pendidikan (KTSP) untuk Kelas XI dan Kelas XII. Guru dalam membuat soal disesuaikan dengan indikator dalam RPP yang mengacu kepada SK dan KD sesuai dengan Silabus dan Kurikulum yang 
digunakan. Soal dibuat dalam bentuk pilihan

ganda dengan menggunakan bantuan software
Hot Potatoes. Selanjutnya, soal ujian diunggah ke server.

Tabel 2. Persentase Jawaban Sampel pada Sub Variabel Bahan dengan Indikator Materi

\begin{tabular}{|l|l|l|c|c|c|c|c|c|l|}
\hline $\begin{array}{c}\text { Sub } \\
\text { Variabel }\end{array}$ & Indikator & $\begin{array}{c}\text { Sub } \\
\text { Indikator }\end{array}$ & No & Pertanyaan & SS & S & RG & TS & STS \\
\hline Bahan & Materi & $\begin{array}{l}\text { Beban } \\
\text { materi } \\
\text { yang } \\
\text { diujikan }\end{array}$ & 4 & $\begin{array}{l}\text { Beban materi yang } \\
\text { diujikan dalam } \\
\text { ujian online tidak } \\
\text { terlalu berat }\end{array}$ & $15 \%$ & $31 \%$ & $15 \%$ & $35 \%$ & $4 \%$ \\
\hline
\end{tabular}

Dari Tabel di atas, diketahui bahwa sebanyak $35 \%$ responden tidak setuju dan $4 \%$ responden menyatakan sangat tidak setuju bahwa beban materi yang diujikan dalam ujian online mudah. Dapat disimpulkan, 39\% responden beranggapan soal ujian sulit

Untuk mendukung kelancaran program ujian online dibutuhkan strategi yang baik dari pihak sekolah. Strategi yang dimaksud berupa fasilitas pendukung yang memadai. Dengan fasilitas yang memadai, program ujian online dapat berjalan dengan baik dan lancar. Namun, hasil temuan di lapangan menunjukkan bahwa fasilitas yang saat ini tersedia masih belum memadai. Terutama dari segi jaringan internet (koneksi wifi) yang belum maksimal. Koneksi wifi yang sering terputus maupun yang tidak sampai ke seluruh bagian sekolah menyebabkan masih banyak siswa dan guru yang tidak dapat menggunakan jaringan wifi. Masalah pada jaringan ini menjadi kendala utama pada saat ujian online berlangsung.

Tabel 3. Persentase Jawaban Sampel pada Sub Variabel Strategi dengan Indikator Fasilitas

\begin{tabular}{|l|l|l|l|l|c|c|c|c|l|}
\hline $\begin{array}{c}\text { Sub } \\
\text { Variabel }\end{array}$ & Indikator & $\begin{array}{c}\text { Sub } \\
\text { Indikator }\end{array}$ & No. & \multicolumn{1}{|c|}{ Pertanyaan } & SS & S & RG & TS & STS \\
\hline Strategi & Fasilitas & $\begin{array}{l}\text { Kelengka } \\
\text { pan } \\
\text { Fasilitas }\end{array}$ & 5 & $\begin{array}{l}\text { Fasilitas yang ada } \\
\text { saat ini sudah } \\
\text { sangat memadai } \\
\text { sehingga saya } \\
\text { dapat } \\
\text { mengerjakan soal- } \\
\text { soal ujian online } \\
\text { dengan lancar. }\end{array}$ & $4 \%$ & $27 \%$ & $27 \%$ & $42 \%$ & $0 \%$ \\
\hline
\end{tabular}

Fasilitas yang disediakan oleh pihak sekolah dirasa masih kurang lengkap. Hal ini dapat diketahui dari Tabel di atas, bahwa sebanyak $42 \%$ responden menyatakan tidak setuju bahwa fasilitas yang ada sudah memadai. Namun, 27\% responden mengaku setuju dan $4 \%$ responden mengaku sangat setuju mengenai kelengkapan fasilitas. Maka, dapat disimpulkan $42 \%$ responden menganggap fasilitas yang tersedia masih kurang memadai 
yang berakibat pada kurang lancarnya responden dalam mengerjakan soal ujian.

\section{Evaluasi Proses}

Ujian online dilaksanakan di ruangan kelas dengan diawasi oleh satu guru. Kondisi ruangan kelas yang digunakan untuk ujian online sudah cukup memadai. Tersedia pula stop kontak untuk memenuhi kebutuhan siswa dalam mengisi ulang baterai laptop.

Tabel 4. Persentase Jawaban Sampel pada Sub Variabel Proses Ujian Online dengan Indikator Kondisi Pelaksanaan Ujian Online

\begin{tabular}{|l|l|l|c|c|c|c|c|c|l|}
\hline \multicolumn{1}{|c|}{$\begin{array}{c}\text { Sub } \\
\text { Variabel }\end{array}$} & Indikator & $\begin{array}{c}\text { Sub } \\
\text { Indikator }\end{array}$ & No. & Pertanyaan & SS & S & RG & TS & STS \\
\hline $\begin{array}{l}\text { Proses } \\
\text { Ujian } \\
\text { Online }\end{array}$ & $\begin{array}{l}\text { Kondisi } \\
\text { Pelaksan } \\
\text { aan Ujian } \\
\text { Online }\end{array}$ & $\begin{array}{l}\text { Kondisi } \\
\text { Kelas } \\
\text { yang } \\
\text { digunaka } \\
\mathrm{n}\end{array}$ & 6 & $\begin{array}{l}\text { Kondisi kelas yang } \\
\text { digunakan untuk } \\
\text { ujian online } \\
\text { membuat saya } \\
\text { nyaman dalam } \\
\text { mengerjakan soal- } \\
\text { soal ujian online }\end{array}$ & $4 \%$ & $23 \%$ & $15 \%$ & $50 \%$ & $8 \%$ \\
\hline
\end{tabular}

Dari tabel di atas dapat diketahui bahwa $50 \%$ responden menyatakan tidak setuju dan $8 \%$ mengaku sangat tidak setuju bahwa kondisi kelas yang digunakan untuk ujian online membuat responden nyaman dalam mengerjakan soal-soal ujian online. Maka, dapat disimpulkan bahwa sebanyak 58\% responden beranggapan kondisi kelas ujian tidak nyaman.
Pada saat awal penerapan ujian online, server ujian online kerap mengalami beberapa kendala antara lain tidak dapat diakses oleh banyak user sekaligus. Untuk mengatasinya, pihak sekolah mencari solusinya dengan browsing melalui internet maupun bertanya ke dalam forum-forum yang berkaitan dan membahas mengenai program tersebut.

Tabel 5. Persentase Jawaban Sampel pada Sub Variabel Proses Ujian Online dengan Sub Indikator Akses Server Ujian Online

\begin{tabular}{|l|l|l|l|l|l|l|l|l|l|}
\hline $\begin{array}{c}\text { Sub } \\
\text { Variabel }\end{array}$ & Indikator & $\begin{array}{c}\text { Sub } \\
\text { Indikator }\end{array}$ & No. & \multicolumn{1}{|c|}{ Pertanyaan } & SS & S & RG & TS & STS \\
\hline $\begin{array}{l}\text { Proses } \\
\text { Ujian } \\
\text { Online }\end{array}$ & Kondisi & Akses & 7 & $\begin{array}{l}\text { Saya tidak } \\
\text { mengalami kendala } \\
\text { dalam mengakses } \\
\text { Server } \\
\text { Ujian } \\
\text { Online } \\
\text { server ujian online } \\
\text { pada saat } \\
\text { mengerjakan soal- } \\
\text { soal ujian online }\end{array}$ & $0 \%$ & $4 \%$ & $8 \%$ & $65 \%$ & $23 \%$ \\
\hline
\end{tabular}


Berdasarkan pada Tabel 3.6 dapat diketahui bahwa $65 \%$ responden tidak setuju dan $23 \%$ responden sangat tidak setuju bahwa responden tidak mengalami kendala dalam mengakses server ujian online. Hal ini dikarenakan server tidak mampu mengakomodir kebutuhan akses seluruh siswa dan mengakibatkan server down. Maka, dapat disimpulkan bahwa sebesar $88 \%$ responden mengalami kendala saat mengakses server ujian online.

Jaringan wifi sekolah dapat digunakan oleh siswa untuk mengakses ujian online, namun tidak semua siswa dapat menggunakan wifi sekolah secara bersamaan. Hal ini dikarenakan ketidakmampuan jaringan wifi sekolah untuk mengakomodir seluruh siswa dalam waktu yang bersamaan

Tabel 6. Persentase Jawaban Sampel pada Sub Variabel Proses Ujian Online dengan Sub Indikator Penggunaan Jaringan Wifi Sekolah

\begin{tabular}{|c|c|c|c|c|c|c|c|c|c|}
\hline $\begin{array}{c}\text { Sub } \\
\text { Variabel }\end{array}$ & Indikator & $\begin{array}{c}\text { Sub } \\
\text { Indikator }\end{array}$ & No. & Pertanyaan & SS & $S$ & RG & TS & STS \\
\hline \multirow[t]{2}{*}{$\begin{array}{l}\text { Proses } \\
\text { Ujian } \\
\text { Online }\end{array}$} & \multirow[t]{2}{*}{$\begin{array}{l}\text { Kondisi } \\
\text { Lainnya }\end{array}$} & \multirow[t]{2}{*}{$\begin{array}{l}\text { Penggun } \\
\text { aan } \\
\text { Jaringan } \\
\text { Wifi } \\
\text { Sekolah }\end{array}$} & 8 & $\begin{array}{l}\text { Saya dapat } \\
\text { menggunakan } \\
\text { jaringan wifi } \\
\text { sekolah untuk } \\
\text { mengerjakan soal- } \\
\text { soal ujian online }\end{array}$ & $4 \%$ & $27 \%$ & $27 \%$ & $35 \%$ & $8 \%$ \\
\hline & & & 9 & $\begin{array}{l}\text { Saya tidak } \\
\text { mengalami } \\
\text { kendala dalam } \\
\text { mengakses situs } \\
\text { ujian online } \\
\text { dengan } \\
\text { menggunakan } \\
\text { jaringan wifi } \\
\text { sekolah }\end{array}$ & $0 \%$ & $4 \%$ & $12 \%$ & $58 \%$ & $27 \%$ \\
\hline
\end{tabular}

Berdasarkan pada Tabel dapat diketahui $35 \%$ responden tidak setuju dan $8 \%$ responden mengaku sangat tidak setuju bahwa responden dapat menggunakan jaringan wifi sekolah untuk mengerjakan soal-soal ujian online. Dari Tabel 3.7 dapat diketahui pula $58 \%$ responden tidak setuju dan $27 \%$ responden mengaku sangat tidak setuju bahwa responden tidak mengalami kendala dalam pengaksesan wifi. Maka dapat dikatakan bahwa $85 \%$ responden mengalami kendala saat menggunakan jaringan wifi sekolah.

Ketika ujian online berlangsung tidak menutup kemungkinan siswa melakukan kecurangan dengan membuka situs lain untuk mencari jawaban atau berkomunikasi dan bertanya kepada teman-temannya melalui media sosial. Hal ini dapat dicegah apabila siswa menggunakan jaringan wifi sekolah untuk mengakses internet. Dengan jaringan wifi, pihak sekolah hanya membuka situs ujian online saja 
sedangkan situs lainnya ditutup dan tidak bisa

ditekan.

dibuka sehingga siswa berbuat curang dapat

Tabel 7. Persentase Jawaban Sampel pada Sub Variabel Proses Ujian Online dengan Sub Indikator Pembatasan Situs

\begin{tabular}{|l|l|l|l|l|c|c|c|c|c|}
\hline $\begin{array}{c}\text { Sub } \\
\text { Variabel }\end{array}$ & Indikator & $\begin{array}{l}\text { Sub } \\
\text { Indikator }\end{array}$ & No. & \multicolumn{1}{|c|}{ Pertanyaan } & SS & S & RG & TS & STS \\
\hline $\begin{array}{l}\text { Proses } \\
\text { Ujian } \\
\text { Online }\end{array}$ & Kondisi & $\begin{array}{l}\text { Pembata } \\
\text { Lainnya }\end{array}$ & 10 & $\begin{array}{l}\text { Saya tidak dapat } \\
\text { Lain } \\
\text { Lengakses situs } \\
\text { Selain } \\
\text { lain selain situs } \\
\text { Situs } \\
\text { Ujian } \\
\text { Online } \\
\text { sekolah pada saat } \\
\text { saya mengerjakan } \\
\text { soal-soal ujian } \\
\text { online }\end{array}$ & $15 \%$ & $15 \%$ & $23 \%$ & $35 \%$ & $12 \%$ \\
& & & & & & & & \\
\hline
\end{tabular}

Berdasarkan Tabel di atas dapat diketahui bahwa $35 \%$ responden tidak setuju dan $12 \%$ responden menyatakan sangat tidak setuju bahwa responden tidak dapat mengakses situs lain selain situs ujian online sekolah pada saat ujian online berlangsung. Namun, 15\% responden sangat setuju dan 15\% responden mengaku sangat setuju bahwa mereka tidak membuka situs lain saat ujian online. Maka dapat disimpulkan bahwa $47 \%$ responden dapat mengakses situs lain selain situs ujian online pada saat ujian berlangsung.

\section{Evaluasi Produk}

Dalam evaluasi produk, dapat diketahui bahwa tujuan dari program ujian online ini sudah banyak yang tercapai terutama dalam hal pengembangan sistem ujian online. Sedangkan tujuan yang belum tercapai adalah belum semua siswa dan guru dapat mengakses wifi sekolah secara nyaman. Untuk hasil ujian online siswa, didapatkan dari hasil test online yang diselenggarakan pada tanggal 30 Oktober 2013. Berdasarkan dari data ujian online tersebut diketahui bahwa nilai rata-rata ujian online dari 26 siswa adalah 72. Apabila menggunakan PAP (Penilaian Acuan Patokan) dengan Kriteria Kelulusan Minimal (KKM) sebesar 75 maka jumlah siswa yang lulus dan tidak lulus masingmasing berjumlah 13 siswa (50\%) dari 26 siswa. Sedangkan apabila menggunakan PAN (Penilaian Acuan Norma) dengan nilai rata-rata kelas sebesar 72, maka siswa yang lulus berjumlah 15 siswa (58\%) dan siswa yang tidak lulus berjumlah 11 siswa (42\%). 


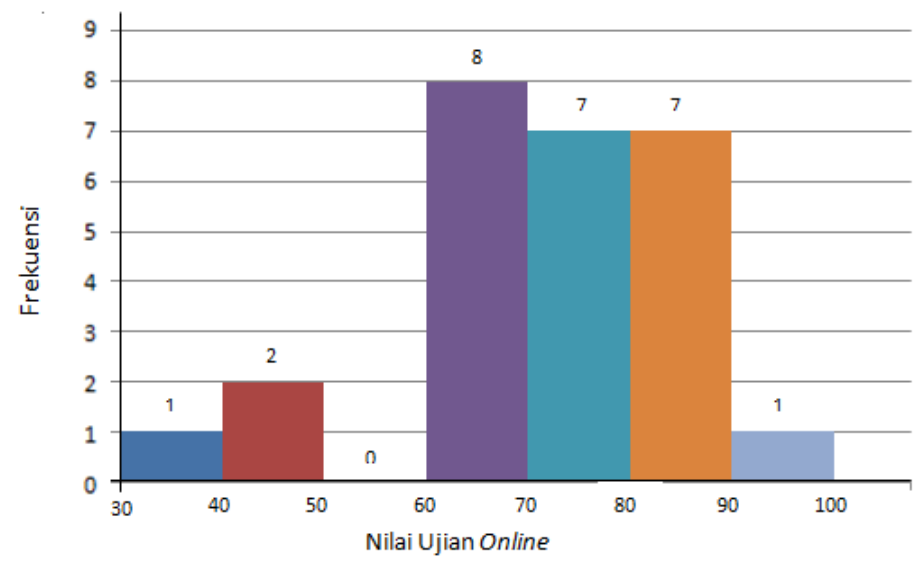

Gambar 1. Skor Hasil Ujian Online Siswa

Penelitian evaluasi pelaksanaan program ujian online ini dilaksanakan untuk mengetahui apakah program ujian online bagi siswa Kelas XII Jurusan Teknik Konstruksi Batu Beton di SMKN 4 Jakarta sudah berhasil atau belum. Dalam penelitian evaluatif ini menggunakan model evaluasi CIPP (Context, Input, Process, Product).

Dalam evaluasi konteks, latar belakang dilaksanakannya program ujian online antara lain sebagai berikut: mengurangi penggunaan kertas (paperless), mengurangi limbah kertas, mengembangkan sistem ujian yang lebih mudah, efektif, dan modern. Sedangkan tujuan dari program ujian online ini adalah: memanfaatkan teknologi komputer dan internet, memudahkan guru dalam melaksanakan evaluasi dan penilaian, memudahkan siswa dalam melaksanakan ujian. Selanjutnya, untuk mengakses program ini (need assessment), Kepala IT membutuhkan program Moodle, software Hot Potatoes, server, jaringan internet atau wifi, dan laptop; guru membutuhkan software Hot Potatoes, jaringan internet dan laptop; sedangkan siswa membutuhkan jaringan internet dan laptop. Hal ini sesuai dengan Computer-based Testing: Practices and Considerations (2010) mengenai manfaat positif dalam melaksanakan program ujian online yang salah satunya adalah kemudahan dalam melaksanakan ujian, dan hasil ujian dapat langsung diketahui.

Dalam evaluasi masukan, kurikulum yang saat ini digunakan yaitu KTSP mendukung adanya program ujian online. Sedangkan untuk penyusunan soal ujian dapat menggunakan bantuan software Hot Potatoes. Kelengkapan fasilitas program ujian online ini masih menjadi permasalahan, terutama dari segi jaringan internet yang tidak stabil. Permasalahan ini telah diungkapkan sebelumnya dalam Computer-based Testing: Practices and 
Considerations menjelaskan mengenai salah satu permasalahan yang berkaitan dengan ujian online antara lain kapasitas teknologi di sekolah, ekonomi (pembiayaan program ujian online), dan aksesbilitas yang masih kurang memadai. Pernyataan ini juga didukung oleh Professional Testing Inc dalam Converting to ComputerBased Testing (2006) mengenai permasalahan yang dihadapi dalam melaksanakan program ujian online yaitu kurangnya sumber daya (operator dan teknologi) yang mendukung.

Dalam evaluasi proses, secara umum proses pelaksanaan program ujian online berjalan lancar hanya terdapat beberapa kendala antara lain ketidakmampuan jaringan wifi dalam mengakomodir seluruh siswa dan server sering down karena tidak mampu menampung jumlah siswa yang mengaksesnya. Sedangkan untuk kondisi ruangan kelas sudah cukup memadai, namun pendingin ruangan tidak berfungsi secara optimal atau terjadi kerusakan sehingga ruangan kelas menjadi panas. Kondisi ruangan ini mempengaruhi kelancaran dan kenyamanan siswa dalam mengerjakan soal ujian online. Mengenai kondisi ruangan kelas telah dijelaskan sebelumnya dalam Converting to ComputerBased Testing (2006) yang diterbitkan oleh Professional Testing Inc. mengenai lokasi ujian online diselenggarakan harus aman dan nyaman untuk peserta ujian.

Dalam evaluasi produk (product evaluation) dapat diketahui bahwa tujuan dari program ini sudah tercapai terutama dalam hal pemanfaatan teknologi komputer dan internet.
Dampak positif dari program ujian online ini adalah saat ini hampir semua guru sudah dapat mengoperasikan komputer dan mengakses internet. Sedangkan, dari hasil perhitungan kuesioner penelitian, diketahui bahwa prosentase keberhasilan program adalah $56,69 \%$. Hal ini menunjukkan bahwa, prosentase keberhasilan program hanya $56,69 \%$ dari yang diharapkan oleh responden.

Dengan demikian, dapat dikatakan bahwa penelitian ini dapat membuktikan kebenaran teori yang telah dibahas sebelumnya mengenai kelebihan dan kekurangan dari program ujian online ini.

\section{KESIMPULAN}

Berdasarkan hasil penelitian "Evaluasi Pelaksanaan Program Ujian Online di SMKN 4 Jakarta", maka dapat ditarik kesimpulan bahwa:

1. Kelebihan dari program ujian online ini antara lain: (a) mempermudah siswa dalam melaksanakan ujian, (b) mempermudah guru dalam melaksanakan evaluasi dan penilaian, (c) hasil ujian dapat langsung diketahui, (d) transparansi penilaian, (e) meningkatnya rasa kepuasan peserta ujian terhadap hasil ujian yang diperoleh, (f) administrasi yang efisien, (g) semua mata pelajaran dapat diujikan.

2. Kekurangan dari program ujian online ini adalah sebagai berikut: (a) kapasitas teknologi masih kurang memadai, (b) kurangnya sumber daya manusia dalam hal pegelolaan program ujian online, (c) biaya 
yang dikeluarkan relatif mahal, (d) koneksi jaringan internet tidak stabil, (e) kondisi ruang ujian kurang nyaman, (f) bentuk soal hanya dapat berbentuk pilihan ganda, (g) siswa diharuskan membawa laptop sendiri, (h) siswa harus menggunakan modem sendiri apabila jaringan wifi sekolah tidak berfungsi, (i) rentan terjadi kecurangan saat ujian online berlangsung, (j) hanya teori kognitif mata pelajaran saja yang dapat diujikan dengan ujian online, (k) sistem ujian online hanya memenuhi tingkatan kognitif rendah, yaitu pengetahuan dan pemahaman (I) dari 45 Kompetensi Dasar yang diajarkan kepada Kelas X, XI, dan XII Jurusan Teknik Konstruksi Batu Beton, hanya 20 Kompetensi Dasar saja yang dapat diujikan teorinya dengan program ujian online.

3. Hasil perhitungan kuesioner penelitian, dapat diketahui bahwa prosentase keberhasilan program adalah $56,69 \%$. Hal ini menunjukkan bahwa, prosentase keberhasilan program hanya $56,69 \%$ dari yang diharapkan oleh responden.

4. Maka, secara keseluruhan program ujian online di SMKN 4 Jakarta dapat dikatakan belum berhasil dan masih banyak hal yang perlu diperbaiki terutama dalam segi jaringan internet (wifi) dan server ujian online.

\section{DAFTAR PUSTAKA}

Anonim. 2006. Converting to Computer-Based Testing.

(online)

http://www.proftesting.com/test_topics/cb t.php [diakses tanggal 15 Mei 2013]

Anonim. 2011. Pengertian Definisi Hasil Belajar. (online).

http://www.sarjanaku.com/2011/03/peng ertian-definisi-hasil-belajar.html [diakses tanggal 12 Mei 2013]

Arikunto, Suharsimi. 1988. Penilaian Program Pendidikan. Jakarta: Departemen Pendidikan dan Kebudayaan

Arikunto, Suharsimi. 2005. Manajemen Penelitian. Jakarta: PT Rineka Cipta

Arikunto, Suharsimi. 2006. Prosedur Penelitian: Suatu Pendekatan Praktek Edisi Revisi VI. Jakarta: PT Rineka Cipta

Bartram, Dave. \& Hambleton, Ronald K. 2006. Computer-Based Testing and the Internet: Issues and Advances. (online) http://books.google.co.id/books?id=FhRb A-ewhdEC\&pg=PA91\&dq=Computer Based+Testingtand+the+Internet:+Issue $s+a n d+A d v a n c e s \& h l=e n \& s a=X \& e i=2 a C 6$ UfCuFOfwOQGU2IDACw\&redir_esc=y [diakses tanggal 17 Mei 2013]

Depdiknas. 2007. Kamus Besar Bahasa Indonesia. Jakarta: Balai Pustaka

Margono. 2005. Metodologi Penelitian Pendidikan. Jakarta: PT Rineka Cipta

Mathis, Robert L. \& Jackson, John Harold. 2012. Human Resources Management, 6th edition: Essential Perspective. 
(online).

http://books.google.co.id/books?id=Ee8z

RSWUjJ8C\&printsec=frontcover\&dq=Ro

bert+I.+Mathis+dan+John+H.+Jackson,+

2004\&hl=id\&sa=X\&ei=bj28Uu2OA4KQrQ

e50oGoBQ\&ved=0CDAQ6AEwAA\#v=on

epage\&q\&f=false [diakses tanggal 13

Mei 2013]

Means, Michael.; Denny, Kelly.; \& Okelberry, Chris. 2013. Internet Computer Based Testing. (online).

http://www.metroinstitute.com/index.php?option

=com_content\&view=article\&id $=42$

[diakses tanggal 13 Mei 2013]

Mustaji. 2011. Pemanfaatan Multi Media untuk

Meningkatkan Kualitas Pendidikan.

(online).

http://pasca.tp.ac.id/site/pemanfaatan-

multi-media-untuk-meningkatkan-

kualitas-pendidikan [diakses tanggal 13

Mei 2013]

Public Service Commission of Canada. 2011.

Paper-and-pencil instruments. (online).

http://www.psc-cfp.gc.ca/ppc-cpp/acs-

cmptnc-evl-cmptnc/pp-instrmnt-pc-

eng.htm [diakses tanggal 1 Juni 2013]

Restifo, Harys. 2009. Evaluasi Program

Pelatihan Operator Tower Crane di Balai

Pelatihan Peralatan Departemen

Pekerjaan Umum. [skripsi]. Jakarta:

Fakultas Teknik, Universitas Negeri Jakarta

Rusmadi, Dedi. 1989. Kamus Komputer.

Bandung: Penerbit M2S
Satori, Djam'an. \& Komariah, Aan. 2009.

Metodologi Penelitian Kualitatif.

Bandung: Alfabeta

Sudaryono. 2012. Dasar-dasar Evaluasi Pembelajaran. Yogyakarta: Graha IImu

Sugiyono. 2009. Metode Penelitian Kuantitatif, Kualitatif, dan R\&D. Bandung: Alfabeta

Sukardi. 2008. Evaluasi Pendidikan: Prinsip dan Operasionalnya. Yogyakarta: Bumi Aksara

Sukardi. 2009. Metodologi Penelitian Pendidikan. Yogyakarta: Bumi Aksara

Sukmadinata. 2008. Metode Penelitian

Pendidikan. Bandung: PT Remaja Rosdakara

Suparman, Atwi. \& Purwanto. 1999. Evaluasi

Program Pendidikan dan Pelatihan.

Jakarta: STIA LAN

Tayibnafis, Farida Yusuf. 2000. Evaluasi

Program. Jakarta: Rineka Cipta

Thurlow, Martha.; Lazarus, Sheryl S.; Albus, Debra.; \& Hodgson, Jennifer. 2010. Computer-based Testing: Practices and Consideration. Synthesis Report 78: 1-4

Wahyono, Joko. \& Toruan, Rayendra L. 2010. Sekolah kaya Sekolah Miskin, Guru Kaya Guru Miskin. (online). http://books.google.co.id/books?id=RIGz M6GBQkIC\&pg=PA134\&lpg=PA134\&dq =penerapan+teknologi+dalam+belajar+jo ko+wahyono\&source $=$ bl\&ots=ozgiMFPJF N\&sig=v8yORF5CMKsuLwVBOX_vY9rM Nao\&hl=en\&sa=X\&ei=OEC8UpqIMleQrQ e0_IGQAQ\&redir_esc=y\#v=onepage\&q= penerapan $\% 20$ teknologi $\% 20$ dalam $\% 20 \mathrm{~b}$ 
elajar\%20joko\%20wahyono\&f=false

[diakses tanggal 13 Mei 2013]

Wirawan. 2012. Evaluasi: Teori, Model, Standar,

Aplikasi, dan Profesi. Depok: PT

Rajagrafindo Persada

Wahana Komputer. 2005. Kamus Lengkap

Dunia Komputer. Yogyakarta: CV Andi

Offset
Wahana Komputer. 2006. Kamus Istilah Internet. Yogyakarta: CV Andi Offset

Veithzal, Rifai. 2003. Kepemimpinan Dan Perilaku Organisasi. Jakarta: PT : Raja Grafindo Persada. 